\title{
FAKTOR-FAKTOR FUNDAMENTAL YANG MEMPENGARUHI RETURN SAHAM DAN DAMPAKNYA TERHADAP FREKUENSI PERDAGANGAN SAHAM SEKTOR INDUSTRI BARANG KONSUMSI PADA BEI TAHUN 2010-2017
}

\author{
Devina Putri Anggraeni, M. Noor Salim \\ Fakultas Ekonomi dan Bisnis, Universitas Mercu Buana, Jakarta
}

\begin{abstract}
Abstrak
Penelitian ini bertujuan untuk menguji dan menganalisis faktor fundamental yang diwakili oleh rasio keuangan yaitu: Return on Asset (ROA) mewakili rasio profitabilitas, Debt to Equity Ratio (DER) mewakili rasio solvabilitas, Current Ratio (CR) mewakili rasio likuiditas, dan Total Asset Turn Over (TATO) mewakili rasio aktivitas, dalam pengaruhnya terhadap return saham dan dampaknya terhadap frekuensi perdagangan saham. Data penelitian diambil dari perusahan yang bergerak di sektor barang konsumsi yang terdaftar di Bursa Efek Indonesia pada tahun 2010-2017. Metode sampling yang digunakan adalah purposive sampling. Dari jumlah populasi sebanyak 41 perusahaan, 21 perusahaan yang memenuhi kriteria digunakan sebagai sampel penelitian. Metode analisis yang digunakan adalah analisis data panel menggunakan Eviews 9. Hasil penelitian menunjukkan bahwa ROA berpengaruh terhadap return saham, sedangkan $D E R, C R$, dan TATO tidak berpengaruh terhadap return saham. ROA, DER, CR, dan TATO berpengaruh secara simultan terhadap frekuensi perdagangan saham, namun hanya TATO yang berpengaruh secara parsial terhadap frekuensi perdagangan saham, sedangkan return saham tidak berpengaruh terhadap frekuensi perdagangan saham.
\end{abstract}

Kata Kunci: $\quad C R, D E R$, return saham, ROA, TATO.

\begin{abstract}
This study aims to examine and analyze the fundamental factors represented by financial ratios, i.e., Return on Assets (ROA) which represents the profitability ratio; Debt to Equity Ratio (DER) which represents the solvency ratio; Current Ratio (CR) which represents the liquidity ratio; and Total Asset Turn Over (TATO) which represents the activity ratio, in its effect on stock returns and their impact on the frequency of stock trading. The research data was taken from the companies of the consumer goods sector listed on the Indonesia Stock Exchange in 2010-2017. The sampling method used was purposive sampling. Of the total population of 41 companies, 21 companies were used as research sample. The analytical method used was panel data analysis run by Eviews 9. The results showed that ROA affects stock returns, while DER, CR, and TATO do not affect stock returns. ROA, DER, $C R$, and TATO simultaneously affect the frequency of stock trading. However, only TATO has a partial effect on the frequency of stock trading, while stock returns do not affect the frequency of stock trading.
\end{abstract}

Keywords: $\quad C R, D E R$, stock return, ROA, TATO.

\section{Pendahuluan}

Investasi dapat diartikan sebagai penanaman modal/uang dalam suatu usaha dengan tujuan memperoleh keuntungan dari usaha tersebut, sebagai wahana dimana dana ditempatkan dengan harapan untuk dapat memelihara atau menaikkan nilai atau memberikan hasil yang 
positif di kemudian hari, untuk meningkatkan dan memaksimalkan kekayaan yang dimiliki. Setiap investasi baik jangka pendek maupun jangka panjang mempunyai tujuan utama yaitu mendapatkan keuntungan yang disebut return. Sejak tahun 2010-2017, total kepemilikan saham masih didominasi oleh investor asing, pada akhir tahun 2017 masih tercatat komposisi PMA sebesar 62,1\%, terlihat adanya peningkatan komposisi PMDN selama tahun 2017 namun karena masih didominasi oleh investor asing maka bila investor asing secara serentak menarik dananya perekonomian Indonesia akan terguncang. Berikut adalah sekilas gambaran dari data investasi di Indonesia.

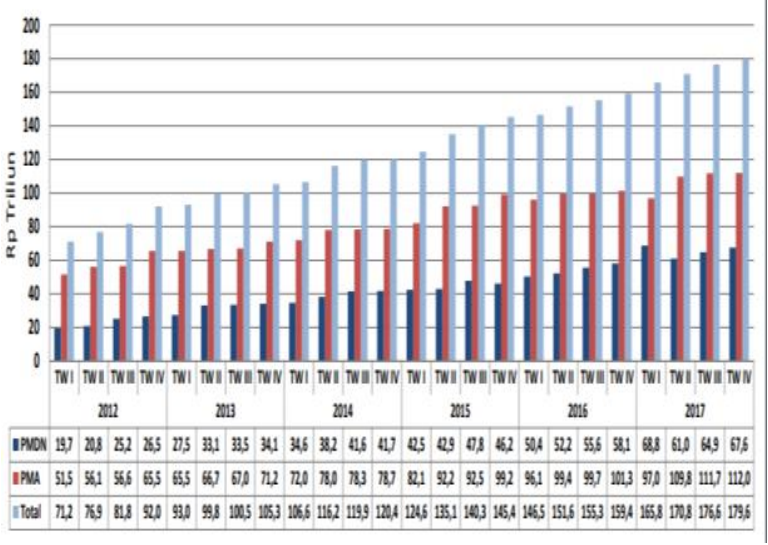

\section{Gambar 1. Komposisi PMA dan PMDN Tahun 2012-2017 \\ Sumber : www.bkpm.go.id}

Realisasi Investasi pada Januari- Desember 2017: Rp 692,8 T, meningkat 13,1\% dari tahun sebelumnya yaitu Januari - Desember 2016 (Rp 612,8 T). Data tersebut membuktikan bahwa masyarakat di Indonesia sudah mulai paham mengenai pentingnya investasi, namun untuk berinvestasi saham diperlukan pemahaman yang baik mengenai keunggulan dan risiko yang ada, tidak disarankan berinvestasi saham berdasarkan feeling ataupun instinct, yang terbaik adalah berinvestasi saham dengan mempertimbangkan faktor-faktor yang dapat dipergunakan untuk menganalisa apakah saham tersebut sesuai untuk dijadikan investasi atau sebaliknya.

Ketika investor memilih untuk menginvestasikan dananya di saham, maka mereka mengharapkan return yang sesuai, oleh sebab itu perlu dianalisa faktor-faktor yang dapat mempengaruhi return saham. Ekspektasi investor dalam berinvestasi saham selain menjadi pemilik suatu perusahaan dengan proposional kepemilikan tertentu, saham yang ditanamkan tersebut diharapkan mampu memberikan tingkat pengembalian atau return tertentu (Kristiana dan Sriwidodo, 2012).

Return adalah tingkat keuntungan yang dinikmati oleh pemodal atas suatu investasi yang dilakukannya. Mengapa return saham bukan harga saham? Return akan memberikan model estimasi yang lebih tepat. Harga saham akan memberikan bias terhadap reaksi investor, karena relatif berubah-ubah terhadap harga saham perusahaan lain, artinya bahwa harga saham yang tinggi belum tentu mencerminkan kinerja saham yang lebih baik dibandingkan harga saham yang lebih rendah.

Return saham dapat dipengaruhi oleh beberapa faktor fundamental seperti ROA, ROE, DER, EPS, CR, TATO, GPM, PBV dan lainnya, dan return saham dapat menjadi indikator bagi investor sebagai pertimbangan dalam keputusan investasinya, penelitian ini peneliti memilih 4 rasio yang masing-masing mewakili rasio keuangan, yaitu: Return on Asset (ROA) mewakili rasio profitabilitas, Debt to Equity Ratio (DER) mewakili rasio solvabilitas, Current Ratio (CR) mewakili rasio likuiditas, dan Total Asset Turn Over (TATO) yang mewakili rasio aktivitas. Berikut beberapa penelitian terdahulu mengenai rasio dan dampaknya terhadap return saham.

Selanjutnya, peneliti memilih sektor industri barang konsumsi untuk diteliti dikarenakan sektor industri barang konsumsi memiliki potensi yang cukup besar untuk perkembangan dari tahun ke tahunnya. Sektor barang konsumsi terdiri dari 6 subsektor yaitu: farmasi, kosmetik dan keperluan rumah tangga, lainnya, makanan dan minuman, peralatan rumah tangga, rokok. 
Tabel 1. Research Gap

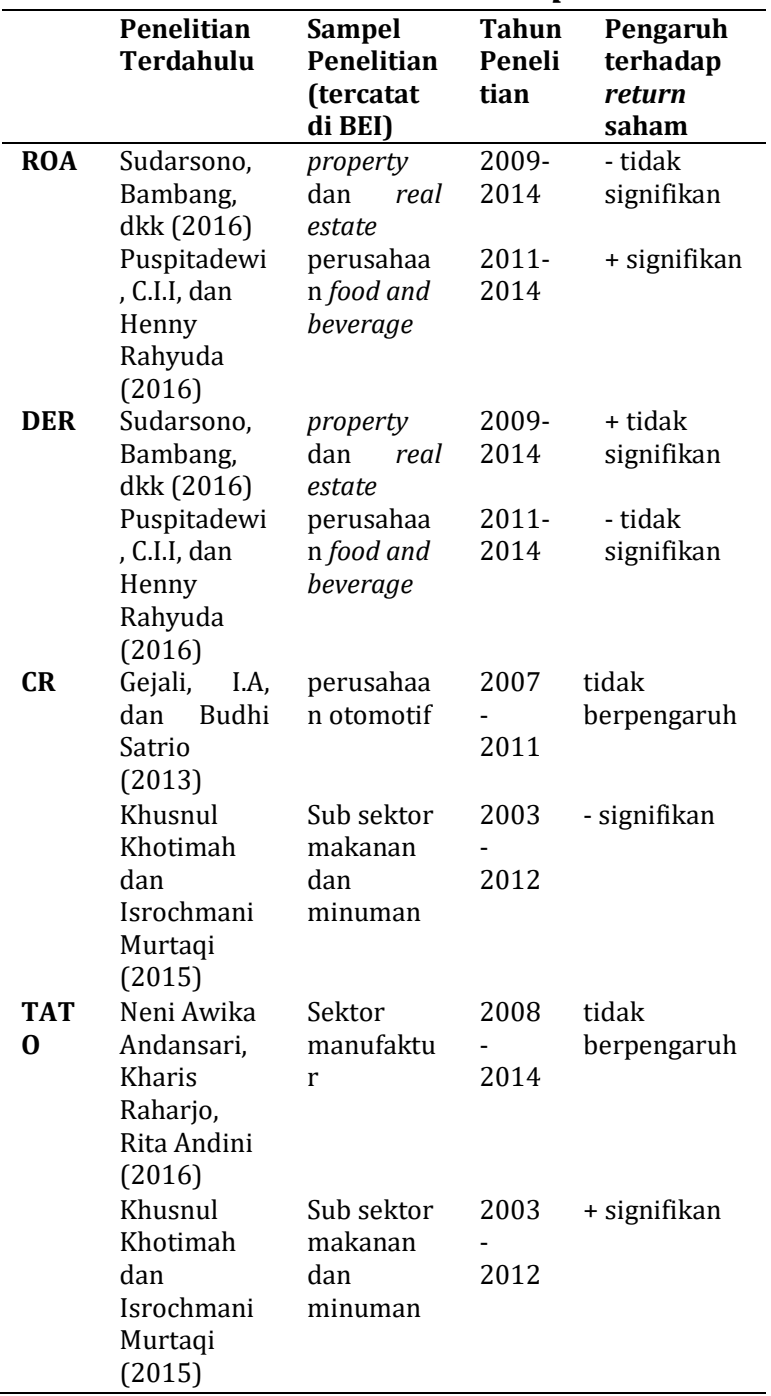

Sumber: www.bps.go.id, 2018

Menurut www.bps.go.id (2018), sebagian besar dari produk domestik bruto digunakan untuk membiayai Konsumsi Rumah Tangga sebesar 55,68\% dan dibandingkan dengan triwulan yang sama tahun sebelumnya (triwulan III tahun 2016), konsumsi rumah tangga naik 4,93\% (dari Rp 1.307.604 milyar di tahun 2016 menjadi Rp 1.372 .053 milyar di tahun 2017). Selain itu kapitalisasi market dalam sektor barang konsumsi juga mengalami peningkatan yang cukup baik dari tahun ke tahun (review dari tahun 20102017), dan sektor barang konsumsi juga dapat menopang sektor lainnya seperti sektor manufaktur pada agustus 2013 diketahui bahwa 31 emiten di sektor barang konsumsi memiliki bobot $44 \%$ dari pembentukan indeks sektor manufaktur. Daya tahan sektor manufaktur terutama ditopang sektor konsumer yang tumbuh 28\%, hal ini membuktikan bahwa sektor barang konsumsi bukan hanya suatu sektor yang berdiri untuk dirinya sendiri melainkan dapat berkontribusi bagi sektor lainnya dan yang menarik adalah ketika return saham pada sektor konsumsi tidak sebaik sektor perbankan secara pergerakannya namun sektor barang konsumsi tetap diminati oleh para investor dan para trader hal ini dapat dilihat dari frekuensi perdagangan saham sektor industri barang konsumsi yang tetap tinggi walaupun return yang didapatkan tidak selalu positif. Hal ini dapat dilihat pada grafik dalam gambar berikut.

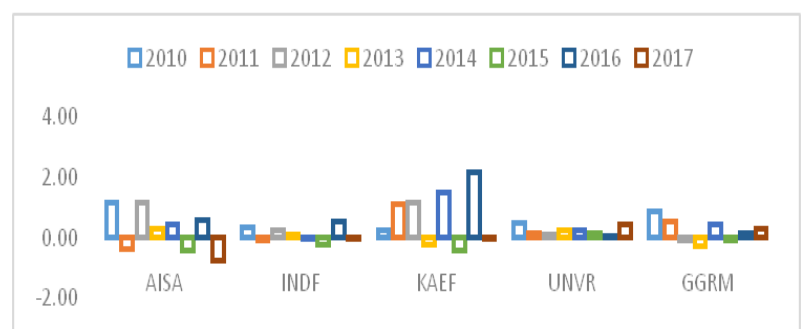

Gambar 2. Pergerakan Return Saham (5 Perusahaan dengan Kinerja Baik) Industri Barang Konsumsi 2010-2017

Sumber : Bursa Efek Indonesia, 2017

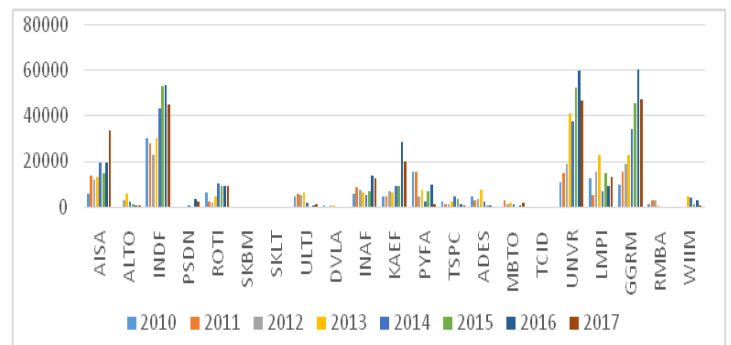

\section{Gambar 3. Frekuensi Penjualan Saham}

Sektor Barang Konsumsi 2010-2017

Sumber: Bursa Efek Indonesia, 2017

Teori sinyal (signaling theory) menjelaskan bahwa pemberian sinyal dilakukan manajemen untuk mengurangi asymetric information antara manajemen perusahaan dengan pihak-pihak yang berkepentingan dengan informasi tersebut. Signaling Theory merupakan suatu prilaku manajemen perusahaan dalam memberi petunjuk untuk investor terkait pandangan manajemen pada prospek perusahaan untuk masa mendatang (Brigham and Houston, 2013). Dapat disimpulkan dikarenakan adaya asymetric information maka pemberian sinyal kepada investor atau publik melalui keputusan- 
keputusan manajemen menjadi sangat penting (Atmaja, 2008).

Teori keagenan (agency theory) menyatakan bahwa pada dasarnya tujuan perusahaan adalah memaksimumkan kemakmuran pemegang saham yang diterjemahkan sebagai memaksimumkan harga saham (Sartono, 2012). Namun dalam kenyataannya tidak jarang manajer memiliki tujuan lain yang mungkin bertentangan dengan tujuan utama tersebut, konflik tersebut sering disebut agency problem. Secara garis besar agency theory merupakan konsep yang menjelaskan hubungan kontraktual atau principle (pihak yang memberikan mandat) dan agent (pihak yang diberikan mandat).

Teori efisiensi pasar menyatakan bahwa pasar yang efisien yaitu the efficient market hyphothesis (EMH) yang berarti suatu pasar dimana harga mencerminkan semua informasi yang diketahui atau know information (Sartono, 2012). Secara garis besar pasar yang efisien adalah pasar dimana harga sekuritas yang diperdagangkan telah mencerminkan semua informasi yang relevan.

Saham adalah tanda penyertaan atau pemilikan seorang atau badan dalam suatu perusahaan atau perseroan terbatas (Darmaji dan Fakhruddin, 2012).

Investasi adalah The creation of money through the use of capital (Harvey, 2012). Tindakan menempatkan modal ke dalam sebuah proyek atau bisnis dengan maksud menghasilkan keuntungan sebagai hasil dari penempatan modal awal.

\section{Metode Analisis Investasi}

Analisis fundamental merupakan pendekatan analisis harga saham yang menitikberatkan pada kinerja perusahaan yang mengeluarkan saham dan analisis ekonomi yang akan mempengaruhi masa depan perusahaan (Sutrisno, 2012).

Analisis teknikal merupakan pendekatan investasi dengan cara mempelajari data historis dari harga saham serta menghubungkan dengan trading volume yang terjadi dan kondisi ekonomi pada saat itu.
Analisis ini hanya mempertimbangkan pergerakan harga saham saja tanpa memperhatikan kinerja perusahaan yang mengeluarkan saham tersebut. Pergerakan harga saham tersebut dihubungkan dengan kejadian-kejadian pada saat itu. Analisis teknikal digunakan oleh para spekulator (Sutrisno, 2012).

Frekuensi perdagangan saham adalah berapa kali terjadinya transaksi jual beli pada saham yang bersangkutan pada waktu tertentu. Dalam aktivitas bursa efek ataupun pasar modal, aktivitas frekuensi perdagangan saham merupakan salah satuelemen yang menjadi salah satu bahan untuk melihat reaksi pasar terhadap sebuah informasi yang masuk pada pasar modal.

Menurut Silviyani, dkk, (2014). Saham yang memiliki frekuensi perdagangan besar diduga dipengaruhi transaksi saham yang sangat aktif, hal ini disebabkan karena banyaknya minat investor, dengan demikian dapat diketahui saham tersebut diminati investor atau tidak.

$$
\overline{\mathbf{x}}=\frac{\text { jumlah frekuensi saham }}{\text { jumlah hari pengamatan }}
$$

Rasio keuangan merupakan kegiatan membandingkan angka-angka yang ada dalam laporan keuangan dengan cara membagi satu angka dengan angka lainnya (Kasmir, 2014).

Rasio profitabilitas merupakan rasio untuk menilai kemampuan perusahaan dalam mencari keuntungan (Kasmir, 2014).

Return on Asset (ROA) merupakan rasio yang menunjukkan hasil (return) atas jumlah aktiva yang digunakan dalam perusahaan (Kasmir, 2014). ROA merupakan rasio yang mengukur tingkat pengembalian dari bisnis atas seluruh aset yang ada dengan kata lain rasio ini menggambarkan efisiensi penggunaan dana dalam perusahaan. ROA didapat dari perbandingan laba bersih dengan total asset perusahaan.

$$
\text { Return On Asset }=\frac{\text { Earning After Tax }}{\text { Total Asset }} .
$$

Rasio solvabilitas (leverage ratio) merupakan rasio yang digunakan untuk mengukur sejauh mana aktiva perusahaan dibiayai dengan 
utang (Kasmir, 2014). Artinya berapa besar beban utang yang ditanggung perusahaan dibandingkan dengan aktivanya.

Debt to Equity Ratio (DER) merupakan rasio yang digunakan untuk menilai hutang dengan ekuitas (Kasmir, 2014). Rasio ini berfungsi untuk mengetahui setiap rupiah modal sendiri yang dijadikan untuk jaminan hutang.

$$
\text { Debt to Equity Ratio }=\frac{\text { Total Hutang }}{\text { Total Ekuitas }}
$$

Rasio likuiditas merupakan rasio yang menggambarkan kemampuan perusahaan dalam memenuhi kewajiban (utang) jangka pendek (Kasmir, 2014).

Current ratio (cr) merupakan rasio untuk mengukur kemampuan perusahaan membayar kewajiban jangka pendek atau utang yang segera jatuh tempo pada saat ditagih secara keseluruhan (Kasmir, 2014).

$$
\text { Current Ratio }=\frac{\text { Aktiva Lancar }}{\text { Hutang Lancar }}
$$

Rasio aktivitas merupakan rasio yang digunakan untuk mengukur efektivitas perusahaan dalam menggunakan aktiva yang dimilikinya (Kasmir, 2014).

Total Asset Turn Over (TATO) merupakan rasio yang digunakan untuk perputaran semua aktiva yang dimiliki perusahaan dan mengukur berapa jumlah penjualan yang diperoleh dari tiap rupiah aktiva (Kasmir, 2014).

$$
\text { TATO }=\frac{\text { Penjualan }}{\text { Total Aktiva }}
$$

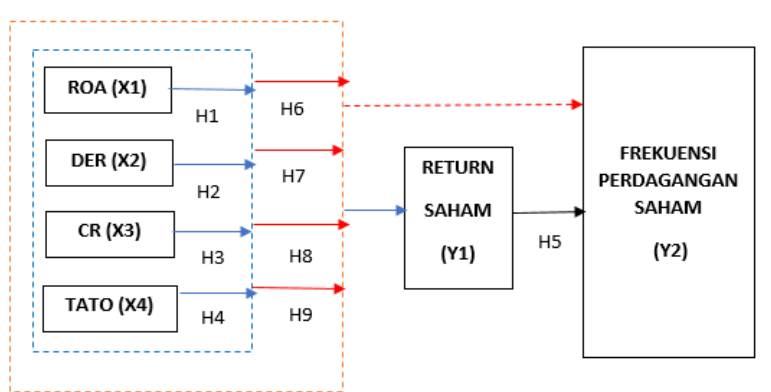

Gambar 4. Kerangka Pemikiran

\section{Metodologi}

Penelitian ini menggunakan metode deskriptif kuantitatif. Jenis penelitian kuantitatif yang digunakan adalah studi korelasional (mempelajari hubungan dua variabel atau lebih, yakni sejauh mana variasi dalam satu variabel berhubungan dengan variasi variabel lain).

Variabel yang dipergunakan:

1. Variabel bebas (Independen Variable) : ROA, DER, CR, TATO.

2. Variabel intervening : return saham.

3. Variabel terikat (Dependen Variable) : frekuensi perdagangan saham.

Metode yang dipergunakan dalam pengambilan sampel adalah non probability purposive sampling dengan menggunakan data panel. Populasi yang digunakan dalam penelitian ini adalah perusahaan-perusahaan go public yang terdaftar di BEI periode tahun 2010-2017 sektor industri barang konsumsi. Adapun kriteria sampel yang akan digunakan sebagai berikut:

1. Perusahaan sektor industri barang konsumsi yang terdaftar di BEI pada tahun 2010-2017.

2. Perusahaan emiten menerbitkan laporan keuangan audited tahunan yang disajikan dalam rupiah secara lengkap selama tahun 2010 - 2017.

3. Perusahaan emiten mempunyai data ROA, DER, CR, TATO, frekuensi perdagangan saham secara lengkap dan selama tahun 2010 - 2017.

4. Perusahaan emiten tidak melakukan stock split atau stock reverse.

5. Merupakan perusahaan yang diminati dalam trading.

Dari kriteria tersebut terdapat sample sebagai berikut:

Tabel 2. Sampel Penelitian

\begin{tabular}{ccc}
\hline Tahun & Populasi & Sampel \\
\hline 2010 & 41 & 18 \\
2011 & 41 & 19 \\
2012 & 41 & 21 \\
2013 & 41 & 21 \\
2014 & 41 & 21 \\
2015 & 41 & 21 \\
2016 & 41 & 21 \\
2017 & 41 & 21 \\
\hline
\end{tabular}

Sumber: data diolah, 2018 
Penelitian ini menggunakan data sekunder yaitu data yang diperoleh secara tidak langsung dari sumbernya melalui dokumendokumen atau catatan tertulis yang diperoleh melalui literatur-literatur, jurnal-jurnal, penelitian terdahulu, dokumen yang diperoleh dari internet. Sumber data berupa laporan keuangan tahunan yang telah dipublikasikan (neraca laporan laba rugi dan laporan trading days saham) dan data yang berupa profil atau gambaran umum perusahaan. Selain itu penulis juga menggunakan data teoritis dari jurnal dan buku-buku referensi. Teknik pengumpulan data adalah dengan riset kepustakaan dan studi internet. Penelitian ini termasuk dalam penelitian deskriptif yaitu penelitian yang berusaha mendeskripsikan suatu gejala peristiwa, kejadian yang terjadi saat sekarang. uji model data panel (chow, hausman, LM), uji asumsi klasik: multikolinearitas dan heteroskedasitas,uji koefisien determinasi R2, uji F, dan uji T. Uji statistik mempergunakan eviews 9.0.

\section{Hasil dan Pembahasan}

\section{Uji Model Data Panel}

\section{Tabel 3. Hasil Uji Model Data Panel}

\begin{tabular}{clll}
\hline Uji Model & Persamaan 1 & Persamaan 2 & Persamaan 3 \\
\hline Uji Chow & Probability & Probability 0 & Probability 0 \\
& $0,31>0,05$ & $<0,05$ & $<0,05$ \\
& maka model & maka model & maka model \\
& terpilih : & terpilih : Fixed. & terpilih : Fixed. \\
& Common. & Dilanjutkan & Dilanjutkan \\
& Dilanjutkan & dengan Uji & dengan Uji \\
Uji & dengan Uji LM. & Hausman. & Hausman. \\
Hausman & - & Probability & Probability \\
& & $0,02<0,05$ & $0,59>0,05$ \\
& & maka model & maka model \\
& & yang tepat: & terpilih: \\
& & Fixed. & random. \\
& & & Dilanjutkan \\
& & & dengan uji \\
Uji LM & P value & - & LM.. \\
& Breusch- & & P value \\
& Pagan 0,5 $>$ & & Breusch- \\
& 0,05 & & Pagan 0 < \\
& maka model & & maka model \\
& yang tepat: & & yang tepat: \\
& Common. & & Random.. \\
\hline
\end{tabular}

Sumber: data diolah, 2018
Dalam penelitian ini terdapat 3 persamaan regresi, sebagai berikut:

\section{Persamaan 1:}

Return saham

$=-0,39-0,81 R O A+0,01 D E R-0,01 C R+$

0,13 TATO + (6)

1. Nilai Koefisien konstanta negatif 0,39 berarti jika nilai ROA, DER, CR, dan TATO yang terjadi sama dengan nol, maka nilai return saham akan mengalami penurunan 0,39 .

2. Nilai koefisien regresi ROA dengan arah negatif sebesar 0,81 berarti apabila terjadi kenaikan ROA sebesar $1 \%$ sementara variabel independen lainnya bersifat tetap maka return saham akan mengalami penurunan sebesar 0,81 (81\%).

3. Nilai koefisien regresi DER sebesar 0,01 dengan arah positif menyatakan bahwa apabila terjadi kenaikan DER sebesar 1\% sementara variabel independen lainnya bersifat tetap maka return saham akan mengalami kenaikan sebesar 0,01 (1\%).

4. Nilai koefisien regresi CR sebesar 0,01 dengan arah negatif berarti apabila terjadi kenaikan CR sebesar 1\% sementara variabel independen lainnya bersifat tetap maka return saham akan mengalami penurunan sebesar 0,01 (1\%).

5. Nilai koefisien regresi TATO sebesar 0,13 dengan arah positif berarti apabila terjadi kenaikan TATO sebesar $1 \%$ sementara variabel independen lainnya bersifat tetap maka return saham akan mengalami kenaikan sebesar 0,13 (13\%).

\section{Persamaan 2:}

Ln Frekuensi perdagangan saham

$$
\begin{aligned}
& =8,43+0,2 \text { ROA + 0,13 DER }-0,03 C R- \\
& 1,01 \text { TATO +e.................... (7) }
\end{aligned}
$$

1. Nilai Koefisien konstanta sebesar 8,43 berarti jika nilai ROA, DER, CR, TATO, dan return saham yang terjadi sama dengan nol, maka nilai frekuensi perdagangan saham akan mengalami kenaikan sebesar 8,43.

2. Nilai koefisien regresi ROA sebesar 0,2 dengan arah positif berarti apabila terjadi kenaikan ROA sebesar $1 \%$ sementara variabel independen lainnya bersifat tetap 
maka frekuensi perdagangan saham akan mengalami kenaikan sebesar 0,2.

3. Nilai koefisien regresi DER sebesar 0,13 dengan arah positif menyatakan bahwa apabila terjadi kenaikan DER sebesar 1\% sementara variabel independen lainnya bersifat tetap maka frekuensi perdagangan saham akan mengalami kenaikan sebesar 0,13 .

4. Nilai koefisien regresi CR sebesar 0,03 dengan arah negatif berarti apabila terjadi kenaikan CR sebesar 1\% sementara variabel independen lainnya bersifat tetap maka frekuensi perdagangan saham akan mengalami penurunan sebesar 0,03.

5. Nilai koefisien regresi TATO sebesar 1,01 dengan arah negatif berarti apabila terjadi kenaikan TATO sebesar $1 \%$ sementara variabel independen lainnya bersifat tetap maka frekuensi perdagangan saham akan mengalami penurunan sebesar 1,01.

Firm Size diukur dengan mentransformasikan total aset yang dimiliki perusahaan ke dalam bentuk logaritma natural Murhadi (2013). Ukuran perusahaan diproksikan dengan menggunakan Log Natural Total Aset dengan tujuan agar mengurangi fluktuasi data yang berlebih. Dengan menggunakan log natural, jumlah aset dengan nilai ratusan miliar bahkan triliun akan disederhanakan, tanpa mengubah proporsi dari jumlah aset yang sesungguhnya, hal ini sejalan dengan penelitian Permana dan Salim (2018) yang mempergunakan Ln dalam pengukuran total assetnya.

\section{Persamaan 3:}

Ln Frekuensi Perdagangan Saham

$=7,2+0,06$ return saham $+e$ (8)

1. Nilai Koefisien konstanta sebesar 7,2 berarti jika nilai return saham yang terjadi sama dengan nol, maka nilai frekuensi perdagangan saham akan mengalami kenaikan sebesar 7,2.

2. Nilai koefisien regresi return saham sebesar 0,06 dengan arah positif berarti apabila terjadi kenaikan return saham sebesar $1 \%$ sementara variabel independen lainnya bersifat tetap maka frekuensi perdagangan saham akan mengalami kenaikan sebesar 0,06.

\section{Uji Asumsi Klasik}

Uji Multikolinearitas

Tabel 4. Hasil Uji Multikolinearitas

\begin{tabular}{ccccc}
\hline & ROA & DER & CR & TATO \\
\hline ROA & 1.000000 & 0.296301 & 0.015846 & 0.516906 \\
DER & 0.296301 & 1.000000 & -0.239160 & 0.058059 \\
CR & 0.015846 & -0.239160 & 1.000000 & -0.095190 \\
TATO & 0.516906 & 0.058059 & -0.095190 & 1.000000
\end{tabular}

Sumber: data diolah, 2018

Dalam Tabel 4 dapat dilihat nilai koefisien korelasi antar variabel independen lebih kecil dr 0,8 sehingga tidak terjadi multikolinearitas.

\section{Uji Heteroskedasitas}

Tabel 5. Probabilitas Uji Heteroskedasitas

\begin{tabular}{lllll}
\hline & ROA & DER & CR & TATO \\
\hline Probabilitas & 0,43 & 0,06 & 0.06 & 0,50
\end{tabular}

Sumber: data diolah, 2018

Probabilitas pada ROA, DER, CR, TATO $>0,05$ oleh sebab itu terbebas dari pelanggaran heteroskedasitas.

\section{$\underline{\text { Koefisien Determinasi }}$}

Koefisien determinasi yaitu kuadrat dari koefisien korelasi $\left(\mathrm{R}^{2}\right)$ yang digunakan untuk mengetahui seberapa besar pengaruh variabel bebas terhadap variabel terikat atau seberapa besar kontribusi variabel X1 (ROA), X2 (DER), X3(CR) dan X4 (TATO) terhadap variabel Y1 (return saham) pada persamaan pertama, dan digunakan untuk mengetahui seberapa besar kontribusi variabel X1 (ROA), X2(DER), $\mathrm{X} 3(\mathrm{CR}), \mathrm{X} 4$ (TATO) terhadap variabel Y2 (frekuensi perdagangan saham) pada persamaan kedua.

Berdasarkan hasil perhitungan uji simultan dengan menggunakan eviews 9.0 untuk mengetahui besarnya pengaruh dari ROA, DER, CR dan TATO secara bersama-sama (simultan) terhadap return saham dapat diketahui dari adjusted R2pada tabel model summary yakni sebesar $0,019 \times 100 \%=1,9 \%$. Angka tersebut menunjukkan bahwa ROA, DER, CR dan TATO mampu menjelaskan return saham sebesar 0,019 atau 1,9\% dan sisanya sebesar $98,1 \%$ disebabkan oleh faktoryang lainyang tidak diteliti misalnya rasio keuangan 
lainnya, kondisi perekonomian (Inflasi, Suku Bunga The Fade Rate, Kurs, BI Rate), keadaan politik dan lain sebagainya, terhadap frekuensi perdagangan saham dapat diketahui dari adjusted R2 pada tabel model summary yakni sebesar $0,827 \times 100 \%=82,7 \%$. Angka tersebut menunjukkan bahwa ROA, DER, CR, TATO mampu menjelaskan frekuensi perdagangan sahamsebesar 0,827 atau 82,7 \% dan sisanya sebesar $17,3 \%$ disebabkan oleh faktor yang lain yang tidak diteliti seperti yang disebutkan sebelumnya.

\section{Uji F (Simultan)}

Berdasarkan hasil perhitungan uji simultan dengan menggunakan eviews 9.0 hasil uji $\mathrm{F}$ pada persamaan 1 diperoleh nilai sig pada tabel adalah 0,13 lebih besar dari nilai probabilitas 0,05 sehingga $\mathrm{H}_{\mathrm{o}}$ diterima dan $\mathrm{H}_{a}$ ditolak, disimpulkan bahwa ROA, DER, CR, dan TATO tidak berpengaruh secara simultan terhadap return saham. Pada pengujian persamaan 2 diperoleh nilai sig pada tabel adalah 0,00 lebih kecil darinilai probabilitas 0,05 maka $\mathrm{H}_{\mathrm{o}}$ ditolak dan $\mathrm{H}_{\mathrm{a}}$ diterima, disimpulkan bahwa ROA, DER, CR, dan TATO berpengaruh secara simultan terhadap frekuensi perdagangan saham.

\section{Uji t (Parsial)}

Pada persamaan 1 nilai sig: $\mathrm{ROA}=0,02$; $\mathrm{DER}=$ 0,$82 ; \mathrm{CR}=0,52$; $\mathrm{TATO}=0,07$; hanya nilai sig ROA yang lebih kecil dari nilai probabilitas 0,05 maka $\mathrm{H}_{\mathrm{a}}$ diterima dan $\mathrm{H}_{\mathrm{o}}$ ditolak sehingga dapat disimpulkan bahwa ROA berpengaruh secara parsial terhadap return saham, namun DER,CR, dan TATO tidak.Pada persamaan 2 nilai sig: $\mathrm{ROA}=0,9 ; \mathrm{DER}=0,16 ; \mathrm{CR}=0,75$; TATO $=0,007$; hanya nilai sig TATO yang lebih kecil dari nilai probabilitas 0,05 maka $\mathrm{H}_{a}$ diterima dan $\mathrm{H}_{\mathrm{o}}$ ditolak sehingga dapat disimpulkan bahwa TATO berpengaruh secara parsial terhadap frekuensi perdagangan saham, namun ROA, DER, dan CR tidak. Pada persamaan 3 nilai sig return saham $=0.31$ lebih besar dari nilai probabilitas 0,05 sehingga maka $\mathrm{H}_{0}$ diterima dan $\mathrm{H}_{\mathrm{a}}$ ditolak sehingga dapat disimpulkan bahwa return saham tidak berpengaruh secara parsial terhadap frekuensi perdagangan saham.

\section{Kesimpulan}

Hasil penelitian menunjukkan bahwa ROA berpengaruh secara parsial terhadap return saham perusahaan sektor industri barang konsumsi di BEI tahun 2010-2017. DER tidak berpengaruh secara parsial terhadap return saham perusahaan sektor industri barang konsumsi di BEI tahun 2010-2017. CR tidak berpengaruh secara parsial terhadap return saham perusahaan sektor industri barang konsumsi di BEI tahun 2010-2017. TATO tidak berpengaruh secara parsial terhadap return saham perusahaan sektor industri barang konsumsi di BEI tahun 2010-2017. Return saham tidak berpengaruh terhadap frekuensi perdagangan saham sektor industri barang konsumsi di BEI tahun 2010-2017.

Hasil penelitian juga menunjukkan bahwa ROA tidak berpengaruh secara parsial terhadap frekuensi perdagangan saham perusahaan sektor industri barang konsumsi di BEI tahun 2010-2017. DER tidak berpengaruh secara parsial terhadap frekuensi perdagangan saham perusahaan sektor industri barang konsumsi di BEI tahun 2010-2017. CR tidak berpengaruh secara parsial terhadap frekuensi perdagangan saham perusahaan sektor industri barang konsumsi di BEI tahun 2010-2017. TATO berpengaruh secara parsial terhadap frekuensi perdagangan saham perusahaan sektor industri barang konsumsi di BEI tahun 2010-2017. ROA, DER, CR, TATO berpengaruh secara simultan terhadap frekuensi perdagangan saham pada perusahaan sektor industri barang konsumsi di BEI tahun 20102017, sejalan dengan teori Du Pont (ROI).

\section{Saran}

Berdasarkan hasil penelitian, studi ini merekomendasikan agar para investor dalam berinvestasi saham patut mempertimbangkan faktor fundamental (ROA, DER, CR, TATO), untuk ROA dan TATO semakin tinggi berarti perusahaan tersebut semakin baik, sedangkan untuk DER dan CR semakin rendah semakin baik.

Berkenaan dengan penelitian selanjutnya, para peneliti dapat megeksplorasi rasio 
keuangan lainnya (faktor fundamental lainnya). Penelitian selanjutnya dapat dikembangkan untuk meneliti sektor lainnya dan tahun selanjutnya. Penelitian selanjutnya juga dapat dikembangkan untuk indikator investasi lainnya seperti volume perdagangan saham atau yang lainnya.

Penelitian ini diarapkan dapat dijadikan sebagai bahan referensi dan pembelajaran mengenai pengaruh ROA terhadap return saham karena dari hasil didapatkan bahwa ROA benar berpengaruh terhadap return saham, dan pengaruh TATO terhadap frekuensi perdagangan saham yang sejalan dengan teori Du Pont (ROI = \% EAT x TATO). Hasil penelitian ini juga dapat menjadi bahan referensi untuk investor khususnya trader dalam penentuannya memilih saham yang terbaik dengan menggunakan analisis fundamental dengan mempertimbangkan ROA dan TATO.

\section{Daftar Referensi}

Andansari, Neni Awika, Kharis Raharjo, Rita Andini. 2016. "Pengaruh Return on Equity, Price Earning Ratio, Total Asset Turn Over dan Price To Book Value terhadap Return Saham(Studi Kasus Pada Perusahaan Manufaktur Sektor Makanan Dan Minuman Yang Terdaftar Di BEI Periode 2008-2014)". Journal of Accounting. Vol.2, No.2.

Atmaja, Lukas Setia. 2008. Teori dan Praktik Manajemen Keuangan. Edisi 1. Andi. Yogyakarta.

Brigham, Eugene F dan Houston, Joel F. 2013. Dasar-Dasar Manajemen Keuangan. Edisi 11 Buku 2. Salemba Empat. Jakarta.

Darmadji, Tjiptono, dan Fakhrudin. 2012. Pasar Modal di Indonesia. Edisi Ketiga. Salemba Empat. Jakarta.

Gejali, I.A, dan Budhi Satrio. 2013. "Pengaruh Current Ratio, Return on Equity, dan Earning per Share terhadap return saham". Jurnal Ilmu \& Riset Manajemen .Vol.2, No.6, hh 115.

Harvey, Campbell \& Graham, John.R. 2012. The Theory And Practice of Corporate Finance: Evidence From The Field. Journal of Financial Economics, 2001, vol. 60, issue 2-3, 187-243.
Murhadi, Werner R.2013. Analisis Laporan Keuangan, Proyeksi dan Valuasi Saham. Jakarta: Salemba Empat.

Kasmir. 2014. Analisis Laporan Keuangan, Edisi Satu, Cetakan Ketujuh. Raja Grafindo Persada. Jakarta.

Khotimah, Khusnul, and Isrochmani Murtaqi. 2015. "The Fundamental Analysis of Indonesian Stock Return (Case Study: Listed Public Companies in Sub-Sector Food and Beverage for The Period 2003-2012)". Journal of Business and Management, Vol.4,No.1, pp.95-104.

Kristiana, Vera Anis dan Sriwidodo Untung.2012. Analisis Faktor Faktor yang Mempengaruhi Return Saham Investor pada Perusahaan Manufaktur di Bursa Efek Indonesia. Jurnal Ekonomi dan Kewirausahaan. Vol 12, No 1 April 2012, pp 1 - 11.

Puspitadewi, C.I.I, dan Henny Rahyuda. 2016. "Pengaruh DER, ROA, dan EVA terhadap Return Saham pada Perusahaan Food and Beverage di BEI". E-Jurnal Manajemen Unud. Vol.5, No.3, hh.1429-1456.

Salim, M.Noor, and Heru Permana. 2018. "The Impact of Firm Size, Firm Maturity and Financial Leverage on Rating and Yield to Maturity". Interciencia Journal. Vol.43, No.3, pp.286-300.

Sartono, Agus. 2012. Manajemen Keuangan Teori dan Aplikasi. Edisi 4. BPFE. Yogyakarta.

Silviyani, dkk. 2014. Pengaruh Likuiditas Perdagangan Saham dan Kapitalisasi Pasar Terhadap Return Saham Perusahaan Yang Berada Pada Indeks Lq45 Di Bursa Efek Indonesia Periode Tahun 2009-2013 (Studi Empiris Pada Perusahaan Lq45 Di Bursa Efek Indonesia). e-Journal S1 Ak Universitas Pendidikan Ganesha Jurusan Akuntansi SI (Volume: 2 No. 1 Tahun 2014).

Sudarsono, Bambang, dan Bambang Sudiyatno. 2016. "Faktor-faktor yang Mempengaruhi Return Saham pada Perusahaan Property dan Real Estate yang Terdaftar pada Bursa Efek Indonesia Tahun 2009 s/d 2014". 30 Jurnal Bisnis dan Ekonomi (JBE), Vol.23, No.1, hh.30-51.

Sutrisno. 2012. Manajemen Keuangan Teori, Konsep, dan Aplikasi. EKONISIA. Yogyakarta.

ww.bps.go.id

www.google.com

www.idx.co.id 